\title{
Anammox bacteria drive fixed nitrogen loss in hadal trench sediments
}

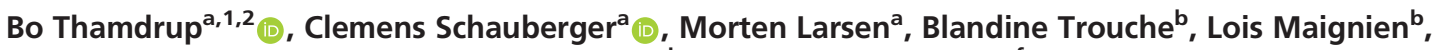 \\ Sophie Arnaud-Haond ${ }^{c}$ (D), Frank Wenzhöfer ${ }^{a, d, e}$, and Ronnie N. Glud ${ }^{a, f, g}$ \\ ${ }^{a}$ Nordcee and HADAL, Department of Biology, University of Southern Denmark 5230 Odense M, Denmark; ${ }^{b}$ Microbiology of Extreme Environments \\ Laboratory, CNRS, Institut Français de Recherche pour L'Exploitation de la Mer, University of Brest, 29280 Plouzané, France; 'MARBEC, Université Montpellier,

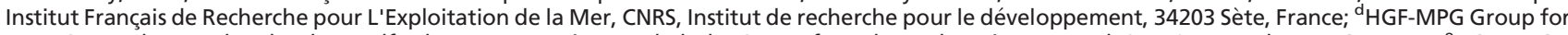 \\ Deep Sea Ecology and Technology, Alfred Wegener Institute Helmholtz Center for Polar and Marine Research 27570 Bremerhaven, Germany; ${ }^{\mathrm{e}} \mathrm{HGF-MPG}$ \\ Group for Deep Sea Ecology and Technology, Max Planck Institute for Marine Microbiology, Bremen 28357, Germany; ${ }^{\mathrm{f} D e p a r t m e n t}$ of Ocean and \\ Environmental Sciences, Tokyo University of Marine Science and Technology, Tokyo 108-8477, Japan; and ${ }^{9}$ Danish Institute of Advanced Study, University of \\ Southern Denmark, 5230 Odense M, Denmark
}

Edited by Edward F. DeLong, University of Hawaii at Manoa, Honolulu, HI, and approved October 11, 2021 (received for review June 11, 2021)

Benthic $\mathrm{N}_{2}$ production by microbial denitrification and anammox is the largest sink for fixed nitrogen in the oceans. Most $\mathrm{N}_{2}$ production occurs on the continental shelves, where a high flux of reactive organic matter fuels the depletion of nitrate close to the sediment surface. By contrast, $\mathrm{N}_{2}$ production rates in abyssal sediments are low due to low inputs of reactive organics, and nitrogen transformations are dominated by aerobic nitrification and the release of nitrate to the bottom water. Here, we demonstrate that this trend is reversed in the deepest parts of the oceans, the hadal trenches, where focusing of reactive organic matter enhances benthic microbial activity. Thus, at $\sim 8-\mathrm{km}$ depth in the Atacama Trench, underlying productive surface waters, nitrate is depleted within a few centimeters of the sediment surface, $N_{2}$ production rates reach those reported from some continental margin sites, and fixed nitrogen loss is mainly conveyed by anammox bacteria. These bacteria are closely related to those known from shallow oxygen minimum zone waters, and comparison of activities measured in the laboratory and in situ suggest they are piezotolerant. Even the Kermadec Trench, underlying oligotrophic surface waters, exhibits substantial fixed $\mathrm{N}$ removal. Our results underline the role of hadal sediments as hot spots of deep-sea biological activity, revealing a fully functional benthic nitrogen cycle at high hydrostatic pressure and pointing to hadal sediments as a previously unexplored niche for anaerobic microbial ecology and diagenesis.

hadal trenches | marine biogeochemistry | microbial ecology denitrification

D ue to an attenuation of the organic matter flux, rates of benthic decomposition in the ocean tend to decline with increasing water depth, and the vast abyssal plains are generally perceived as low-activity deserts (1). As benthic respiration rates decrease with increasing water depth, the depth of oxygen penetration into the sea floor increases and pathways of carbon oxidation shift from predominantly anaerobic in coastal sediments to aerobic in the deep sea (2). Benthic nitrogen transformations are also primarily controlled by the amount of labile organic matter deposited to the sea floor (3). Here, the organics act directly as a source of ammonium for nitrification and anammox and as electron donors for denitrification, while the control on oxygen penetration exerted by flux of organic matter also affects the balance between aerobic nitrification and anaerobic denitrification and anammox $(1,4)$. Thus, the anaerobic processes show even stronger attenuation than aerobic respiration with increasing water depth (3). In this perspective, hadal sediments located at $>6-\mathrm{km}$ depth would be predicted to represent the low-activity end member dominated by aerobic diagenesis. However, a recent study demonstrated higher benthic oxygen respiration rates at $11-\mathrm{km}$ depth in the Challenger
Deep than on the adjacent abyssal plain $5 \mathrm{~km}$ above (5). Together with other studies indicating increased deposition of reactive organics and increased microbial activity in hadal trench sediments (6-8), this raises the potential that anaerobic microbial processes, such as denitrification and anammox, may be active in these settings, and functional genes related to these pathways have indeed been detected in trench axis sediments $(9,10)$. However, the functioning of the microbial nitrogen cycle under high hydrostatic pressure remains unexplored. Important questions include whether microbial nitrogen transformations are indeed stimulated relative to abyssal depths, how this affects the balance between recycling and removal of fixed nitrogen in these systems, which organisms are involved, and how their activity is affected by hydrostatic pressure.

For a first quantification of rates and pathways of nitrogen cycling in hadal trench sediments, we combined geochemical and biomolecular analyses with experimental incubations carried out both in the laboratory and in situ using an autonomous benthic lander. These techniques were applied to sediments

\section{Significance}

Hadal trenches represent the deepest part of the oceans, apparently offering adverse conditions for life, given their high hydrostatic pressure and wide separation from the productive surface waters. However, focusing of reactive organic matter in trench axis sediments potentially promotes complex yet unexplored microbial communities and associated biogeochemical processes. We demonstrate that hadal sediments at depths reaching $10 \mathrm{~km}$ are hotbeds for anaerobic nitrogen transformations, dominated by the anammox process, extending the known depth range of this process by $\sim 6 \mathrm{~km}$. The diversity and phylogeny of identified hadal anammox bacteria suggest that high hydrostatic pressure has not been a major evolutionary driver. Our results provide insights into hadal biogeochemistry and the ability of microbes to adapt to hydrostatic pressure.

Author contributions: B. Thamdrup, M.L., L.M., S.A.-H., F.W., and R.N.G. designed research; B. Thamdrup, C.S., M.L., B. Trouche, F.W., and R.N.G. performed research; B. Thamdrup, C.S., M.L., B. Trouche, L.M., S.A.-H., and R.N.G. analyzed data; and B. Thamdrup wrote the paper with input from C.S., M.L., B. Trouche, L.M., S.A.-H., F.W., and R.N.G.

The authors declare no competing interest.

This article is a PNAS Direct Submission.

Published under the PNAS license.

${ }^{1}$ Present address: Department of Biology, University of Southern Denmark, 5230 Odense M, Denmark.

${ }^{2}$ To whom correspondence may be addressed. Email: bot@biology.sdu.dk.

This article contains supporting information online at http://www.pnas.org/lookup/ suppl/doi:10.1073/pnas.2104529118/-/DCSupplemental.

Published November 10, 2021. 
from two trenches: the Atacama Trench in the highly productive Humboldt Current System and the Kermadec Trench underlying oligotrophic waters of the East Pacific.

\section{Results and Discussion}

We sampled sediment cores along the axis of the contrasting Atacama and Kermadec Trenches, including locations near the deepest point in each trench $(8,085$ and $10,010 \mathrm{~m}$, respectively; SI Appendix, Table S1). Porewater analysis demonstrated steep nitrate gradients within the sediments, with nitrate reaching depletion at 5 to $10 \mathrm{~cm}$ in the Atacama Trench and at 15 to 20 $\mathrm{cm}$ at three of four sites in the Kermadec Trench, where one site had nitrate at $>30 \mathrm{~cm}$ (Fig. $1 A$ and SI Appendix, Fig. S1). The profiles indicated nitrate production by nitrification in the oxic zone and consumption at anoxic depths, with oxygen penetration depths measured in situ with a benthic lander (11). Overall, the thicknesses of the oxic and the nitrogenous zones [i.e., the anoxic part of the nitrate-containing zone (12)] were of similar magnitude. This zonation contrasted with measurements in sediment from the abyssal plains adjacent to the trenches, where nitrate accumulated and no clear downward gradient could be discerned (Fig. 1A), in accordance with oxygen penetration depths of $>20 \mathrm{~cm}$ at these sites (11) and as typical for the abyssal realm (e.g., refs. 13 through 15). Mean rates $( \pm \mathrm{SE})$ of nitrification and nitrate consumption estimated from the profiles assuming steady state were $35 \pm 15$ and $24 \pm$ $8 \mu \mathrm{mol} \cdot \mathrm{m}^{-2} \cdot \mathrm{d}^{-1}$, respectively, in the Atacama Trench and $34 \pm 8$ and $14 \pm 5$ in the Kermadec Trench (Table 1). Thus, 68 and $42 \%$, respectively, of the nitrate generated from nitrification was consumed within the sediment. This distinguishes our hadal sediments from abyssal sites, where 80 to $90 \%$ of the nitrate from nitrification is estimated to be recycled to the overlying water (e.g., refs. 3 and 15). Indeed, the nitrate penetration depths in the sediments from the bottom of Atacama Trench are comparable to those found at 1- to $3-\mathrm{km}$ depth on continental margins (e.g., refs. 16 and 17).

Ammonium only accumulated below the depth of nitrate depletion, indicating efficient anaerobic ammonium oxidation to $\mathrm{N}_{2}$ (Fig. $1 B$ and SI Appendix, Fig. S1). The flux of ammonium into the nitrogenous zone averaged $21 \pm 8 \mu \mathrm{mol} \cdot \mathrm{m}^{-2} \cdot \mathrm{d}^{-1}$ in the Atacama Trench and $12 \pm 6 \mu \mathrm{mol} \cdot \mathrm{m}^{-2} \cdot \mathrm{d}^{-1}$ in the Kermadec Trench (Table 1; for stations at which samples covered the entire nitrogenous zone), which corresponds to 84 to $88 \%$ of the downward flux of nitrate into the anoxic sediment and indicates large contributions of ammonium oxidation to nitrate consumption. The nitrate and ammonium fluxes correspond to total dissolved inorganic nitrogen sinks of $45 \pm 12$ and $26 \pm$ $8 \mu \mathrm{mol} \cdot \mathrm{m}^{-2} \cdot \mathrm{d}^{-1}$ in Atacama and Kermadec Trenches, respectively.

The presence of anaerobic ammonium oxidation in the hadal sediments was confirmed in anoxic incubations with ${ }^{15} \mathrm{~N}$-labeled substrates. In both trench axes, we consistently observed ${ }^{15} \mathrm{~N}-\mathrm{N}_{2}$ production in incubations with ${ }^{15} \mathrm{~N}$-labeled ammonium and unlabeled nitrate, with rates peaking in the nitrate-ammonium transition zone (Fig. $1 C$ and $E$ ). More than $97 \%$ of the ${ }^{15} \mathrm{~N}$-labeled $\mathrm{N}_{2}$ produced was of mass $29\left({ }^{14} \mathrm{~N}^{15} \mathrm{~N}\right)$ as characteristic of anammox (18), and the rates resembled anammox rates determined in incubations with ${ }^{15} \mathrm{~N}$-nitrate and ${ }^{15} \mathrm{~N}$-nitrite in parallel (SI Appendix, Fig. S2), all suggesting that anammox bacteria are active in the trench axis sediments. Denitrification also contributed to $\mathrm{N}_{2}$ production, but rates were generally lower and tended to peak at shallower depths than anaerobic ammonium oxidation. Thus, the average relative contribution of anammox to $\mathrm{N}_{2}$ production in the nitrogenous zone was $67 \pm 13 \%$ in the Atacama Trench, and it reached 91 to $98 \%$ at two sites in the Kermadec Trench (Table 1).
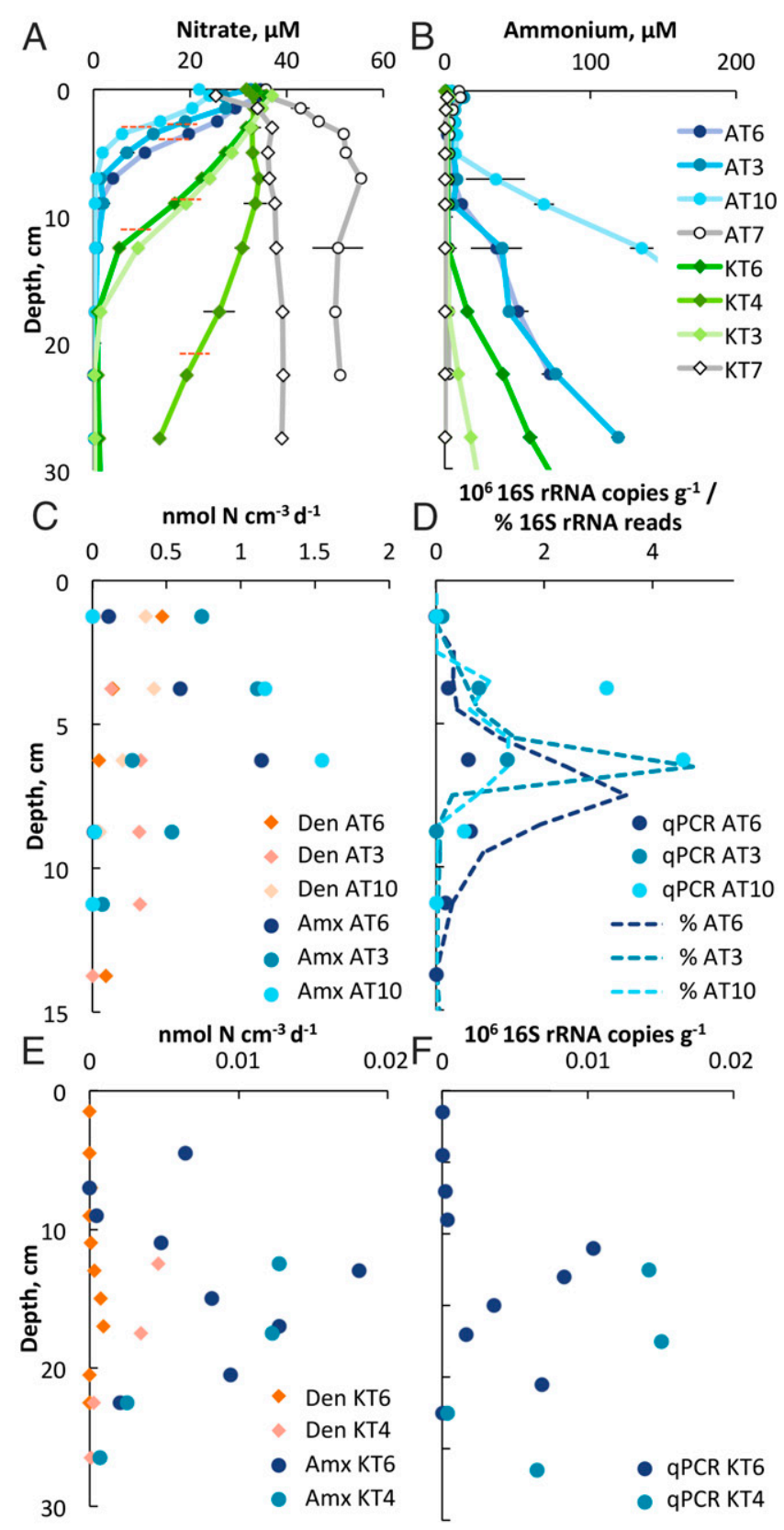

Fig. 1. Porewater distributions, experimental $\mathrm{N}_{2}$ production rates, and distributions of anammox bacteria in sediments from the Atacama (AT) and Kermadec (KT) trenches. ( $A$ and $B$ ) Porewater distributions of nitrate and ammonium, respectively, at three sites from the KT in blue and three sites from the AT in green. For each trench, the sites represent the southern end (KT6 and AT6), center (KT3 and AT4), and northern end (KT10 and AT3) of the transects investigated. Profiles from the adjacent abyssal plain are shown for comparison (open symbols; KT7 and AT7). Stippled orange lines in A represent oxygen penetration depths. Data for all sites is shown in SI Appendix, Fig. S1. (C) Rates of $\mathrm{N}_{2}$ production by denitrification and anammox in the Atacama Trench as determined in shipboard incubations for the same sites as shown in panels $A$ and $B$. (D) Depth distributions of Scalindua 16S rRNA gene copy numbers determined with QPCR and the relative abundance of Scalindua 16S rRNA gene reads in percent of total reads obtained by amplicon sequencing with universal primers at the same sites as in $C$. (E) Same as $C$ for the Kermadec Trench (rates for KT3 were not available). ( $F$ ) Depth distributions of Scalindua $16 \mathrm{~S}$ rRNA gene copy numbers determined with qPCR in the same sites as in $E$.

Anaerobic nitrate consumption has been indicated in hadal porewater profiles $(9,10,19)$, and anammox bacteria have been detected in sediment from the Ogasawara Trench (9), but, as 
Table 1. Nitrogen budget for hadal sediments of the Atacama and Kermadec Trenches based on diffusive fluxes $\left(\mathrm{mmol} N \cdot \mathrm{m}^{-2}\right.$

$\mathrm{d}^{-1}$; average $\pm \mathrm{SE}$ ) and the relative contribution of anammox to $\mathrm{N}_{2}$ production determined experimentally

Atacama Trench*

Kermadec Trench $^{\dagger}$

\begin{tabular}{lll}
\hline Nitrate efflux & $11 \pm 27$ & $19 \pm 6$ \\
Nitrate flux down & $24 \pm 8$ & $14 \pm 5$ \\
Nitrification & $35 \pm 15$ & $34 \pm 8$ \\
Ammonium flux up & $21 \pm 8$ & $12 \pm 6$ \\
$\mathrm{~N}_{2}$ production, fluxes & $45 \pm 12$ & $26 \pm 8$ \\
$\% \mathrm{~N}_{2}$ from anammox & $67 \pm 13$ & $91-98^{\ddagger}$ \\
\hline
\end{tabular}

${ }^{*} n=6$.

${ }^{\dagger} n=4$.

${ }^{ \pm}$Range of two sites.

yet, no experimental evidence of hadal denitrification or anammox activity was reported. While the ability to denitrify is widespread among bacteria, anaerobic ammonium oxidation is only known from the phylogenetically distinct anammox bacteria of the candidate order Brocadiales. Thus, we used biomolecular techniques to further link the observed process to anammox bacteria and to explore whether distinct clades thrive under hadal conditions. Indeed, the copy number of anammox bacterial 16S ribosomal RNA (rRNA) genes in the sediments determined with qPCR agreed well with the measured rates (Fig. 1 $D$ and $F$ ). Counts were near the detection limit in the oxic zone but increased to peak in the nitrogenous zone, indicating growth of anammox bacteria, and decreased again below the depth of nitrate penetration. Counts reached $>10^{6} \cdot \mathrm{g}^{-1}$ at several sites in the Atacama Trench but remained $<10^{5} \cdot \mathrm{g}^{-1}$ in the Kermadec Trench, consistent with the lower rates measured there. Similarly, we observed a close match between the estimated anammox rates and the relative abundance of anammox bacterial 16S rRNA gene sequence variants in a large amplicon dataset from the two trenches (Fig. $1 D$ ). The relative abundance peaked at 1.7 to $4.9 \%$ of all reads in the nitrogenous zone in the Atacama Trench and 0.2 to $0.4 \%$ in the Kermadec Trench. Since total cell counts in the two trenches were similar (20), this is consistent with the relative difference in qPCRbased counts, though lower depth resolution of the profiles in the Kermadec Trench might have smeared peak values (5- or $15-\mathrm{cm}$ sections versus $1-\mathrm{cm}$ sections in Atacama at the depths of interest).

We conclude that porewater chemistry, experimental rate measurements, and biomolecular analyses all point to anammox bacteria being abundant, active, and dominant contributors to fixed nitrogen removal in both of the hadal trench axes explored here. The relative contributions of anammox to $\mathrm{N}_{2}$ production are at the high end of the range reported from aquatic sediments $(21,22)$, with the Kermadec Trench values of $>90 \%$ representing an extreme. With denitrification and anammox in marine sediments both being fueled by the degradation of organic matter and assuming molar C:N ratios at the Redfield ratio of 6.6 or higher, anammox contributions much above $30 \%$ indicate the occurrence of other terminal electron accepting processes than denitrification in the nitrogenous zone (22, 23). Dissimilatory manganese reduction has been suggested as a likely candidate in manganese oxide-rich sediments $(24,25)$ and may also explain the high contributions here. Thus, reactive manganese peaked at concentrations of 33 to $200 \mu \mathrm{mol} \cdot \mathrm{g}^{-1}$ near the depth of oxygen penetration and was depleted through the nitrogenous zone, while dissolved manganese accumulated in the porewater (SI Appendix, Fig. S3). Estimated diffusive fluxes of dissolved manganese indicated a net production of $19 \pm 5 \mu \mathrm{mol} \cdot \mathrm{m}^{-2} \cdot \mathrm{d}^{-1}$ in the nitrogenous zone of the Atacama Trench and 22 to $39 \mu \mathrm{mol} \cdot \mathrm{m}^{-2} \cdot \mathrm{d}^{-1}$ for two sites in the
Kermadec Trench. These values likely underestimate manganese reduction rates in the nitrogenous zone due to limited spatial resolution of profiles and the potential for precipitation of reduced manganese (26), but the values confirm that manganese is a quantitatively important anaerobic electron-accepting process here. Alternative explanations for the high relative contribution of anammox to $\mathrm{N}_{2}$ production could be that nitrate reduction produces nitrite or ammonium rather than $\mathrm{N}_{2}$ as the end product, as observed in oceanic oxygen minimum zones (OMZs) (27). However, although nitrite accumulated in the nitrogenous zone, concentrations maximally reached $2.7 \mu \mathrm{M}$ (SI Appendix, Fig. S1). Likewise, dissimilatory nitrate reduction to ammonium was previously found to be of minor importance in deep-sea sediments (28).

The 16S rRNA gene amplicons of anammox bacteria revealed a wide diversity with strong dominance of the candidate genus Scalindua (Fig. 2 and SI Appendix, Fig. S4), as generally observed in marine environments (29). Thus, of 47 unique amplicon sequence variants (ASVs) in the hadal sediments assigned to Brocadiales, 36 were affiliated to Scalindua. Two ASVs were affiliated to Kuenenia, and the remaining eight were not assigned to any genus, but these non-Scalindua ASVs all occurred sporadically, each in $\leq 4$ of the 166 hadal samples analyzed. By contrast, in the Atacama Trench, five Scalindua ASVs (Nos. 191, 416, 566, 983, and 1,460) occurred in 22 to $57 \%$ of all samples and in 33 to $97 \%$ of samples from the nitrogenous zone, and four of these each reached relative abundances of $>0.5 \%$ of all reads in individual samples (Fig. 2 and SI Appendix, Fig. S5). The smaller Kermadec dataset was phylogenetically similar to that from Atacama, with six of eight ASVs from the Kermadec also occurring in the Atacama Trench. Moreover, the two most abundant hadal lineages in the Atacama Trench (ASV191 and 416) were also among the most abundant Scalindua lineages at bathyal $(2,560 \mathrm{~m})$ and abyssal $(4,050 \mathrm{~m})$ depth on the continental slope (SI Appendix, Fig. S3). Thus, while there were differences in relative abundances between the hadal trenches and even within the Atacama Trench itself, the hadal communities were phylogenetically similar and the dominant hadal lineages also thrived at lower hydrostatic pressure.

The similarity of the hadal anammox communities from the two trenches was further confirmed by the analysis of genes for hydrazine synthase ( $h z s A)$, a unique marker of the anammox process $(30,31)$ in a smaller set of 18 hadal samples (SI Appendix, Fig. S6). At the finer phylogenetic resolution of this approach, sequence variants from the two trenches differed, but most of the more widespread variants still clustered closely together and also together with variants from the abyssal sites.

The Scalindua phylotypes identified in the 16S rRNA gene dataset were spread widely across the phylogenetic tree of the candidate genus (Fig. 2). Surprisingly, the most abundant phylotypes from both trenches were closely related to anammox bacteria from a few hundred meters of water depth in the oceanic OMZs of the Arabian Sea and the eastern tropical North Pacific $(32,33)$ rather than to candidate species of benthic origin. Previous studies of benthic and pelagic anammox bacteria delineated distinct pelagic and benthic clades based on $16 \mathrm{~S}$ rRNA gene phylogeny $(32,33)$, but our study suggests that this distinction is not related to the physical environment itself but rather to the biogeochemical conditions. Thus, the hadal sediments studied here were characterized by broad nitrogenous zones with nitrate and nitrite in the micromolar range and low ammonium concentrations and essentially free of reduced iron (SI Appendix, Fig. S3) and of bioturbation, as indicated by visual layering (20). These redox conditions are similar to those found in the anoxic core of OMZs (34), while previous studies of benthic anammox bacteria have mainly focused on coastal and continental shelf sites (e.g., ref. 35), where the redox 


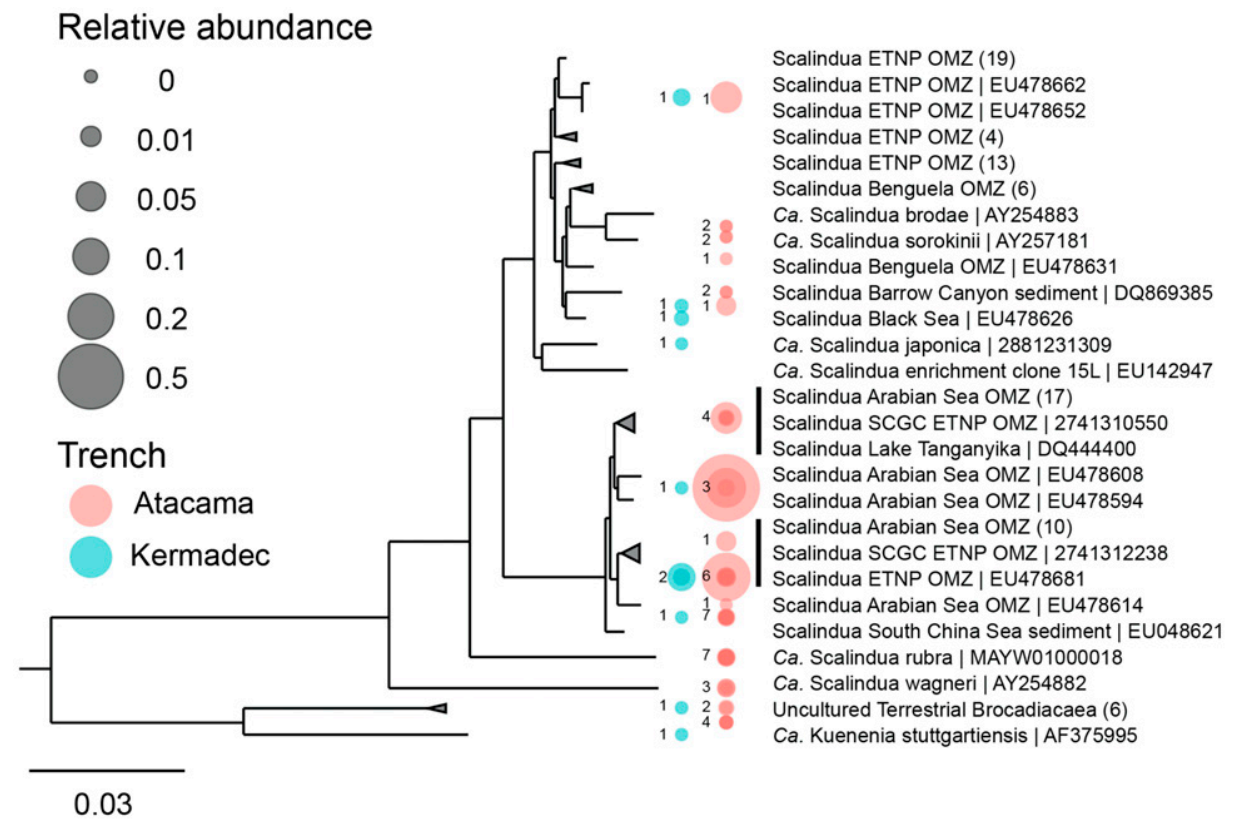

Fig. 2. Maximum likelihood tree (IQTree) of anammox 16S rRNA gene sequences. The most likely placement (RAxML EPA) of ASVs obtained from sediments within the Kermadec Trench (turquoise) and the Atacama Trench (red) are shown next to the respective clades as bubbles. Bubble size indicates the relative abundance of each ASV with overlay of bubbles assigned to the same node. The number of ASVs with the same placement is indicated to the left of the respective bubbles. The scale on the bottom left indicates the estimated substitutions per nucleotide. See SI Appendix, Fig. S3 for a version of the tree without collapsed branches.

zonation is generally more compressed and where bioturbative mixing reaches into ferruginous or even sulfidic horizons (e.g., refs. 26 and 36), resulting in highly fluctuating environmental conditions for an anammox bacterium. We suggest that the phylogenetic clusters within the genus Scalindua reflect adaptation to these differing conditions.

Another explanation for the close relationship between lineages from OMZs and trenches could be that OMZ waters serve as a dominant source for anammox bacteria in the deep sea. Our northern sites in the Atacama Trench are directly under such an OMZ, where anammox is active and anammox bacteria are abundant $(37,38)$. However, the Kermadec Trench is almost $10,000 \mathrm{~km}$ from the eastern Pacific OMZs, and it thus appears that the composition of the anammox community is controlled by selection within the benthic environment.

Whereas adaptations to high hydrostatic pressure are well documented for other bacteria (39-41), our analysis indicates that if such adaptations exist in anammox bacteria, they have not been associated to an evolutionary bottleneck giving rise to distinct hadal or even deep-sea clades but must occur so frequently that they are hidden in microdiversity that is not resolved by the $16 \mathrm{~S}$ rRNA analysis. Furthermore, the experimental rate measurements in shipboard incubations document the ability of hadal anammox bacteria to metabolize at surface pressure. In the Atacama Trench, where the most detailed dataset was available, average anammox rates for sediment from the nitrogenous zone measured in the laboratory $\left(0.41 \pm 0.21 \mathrm{nmol} \cdot \mathrm{cm}^{-3} \cdot \mathrm{d}^{-1}\right)$ were similar to the in situ rates of $0.24 \pm 0.08 \mathrm{nmol} \cdot \mathrm{cm}^{-3} \cdot \mathrm{d}^{-1}$ that could be estimated from the porewater nitrate profiles, the thickness of the nitrogenous zone, and the relative importance of anammox from the incubations (Table 1). Rates from batch incubations as performed here are generally interpreted as potential rates because the amendment of nitrate and/or ammonium will stimulate activity if the microbes are limited by the substrates in situ $(24,25)$. However, due to a high affinity for nitrite $(24,42)$, anammox bacteria might only be electron acceptor limited at the very bottom of the nitrogenous zone when this zone is as well developed as in the hadal sediments (Fig. $1 A$ ), justifying the use of batch-based rates as estimates of in situ activity (43). Thus, although these rate estimates, as well as those derived from concentration gradients, should only be considered as approximations, the similarity indicates that anammox bacteria are not severely inhibited by decompression, suggesting that they are piezotolerant rather than piezophilic.

With the ultimate aim of quantifying in situ activity directly, we let an autonomous benthic lander perform injections of ${ }^{15} \mathrm{~N}$-labeled nitrate and nitrite into sediment cores at two sites at the bottom of the Atacama Trench. In both cases, the production of ${ }^{15} \mathrm{~N}$-labeled $\mathrm{N}_{2}$ was detected, and the depth distributions of activity were similar to those obtained in the laboratory

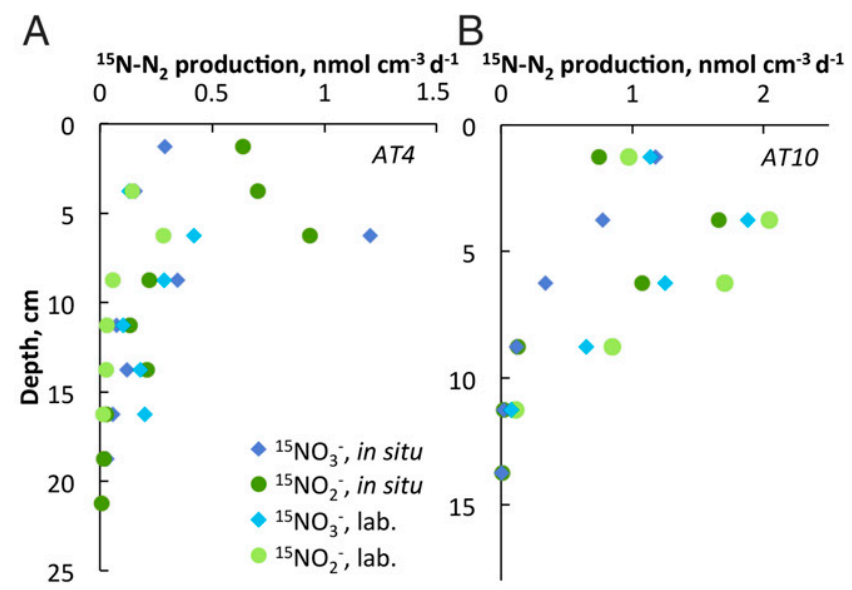

Fig. 3. Comparison of ${ }^{15} \mathrm{~N}-\mathrm{N}_{2}$ accumulation rates in hadal sediments determined with in situ whole-core incubations with a benthic lander (diamonds) and shipboard experiments (circles) with added ${ }^{15} \mathrm{~N}$-labeled nitrate (blue) or nitrite (green). Incubations were made at two sites, AT4 $(A)$ and AT10 $(B)$ in the Atacama Trench. 
incubations (Fig. 3). The amounts of ${ }^{15} \mathrm{~N}-\mathrm{N}_{2}$ accumulated were also in broad agreement with the production in the laboratory incubations, with in situ values exceeding those from the laboratory at site AT4, whereas the opposite was the case at AT10. While further tests are required to validate in situ metabolic rates from the lander incubations, the consistency between the two types of incubation again suggests that the activity of $\mathrm{N}_{2}$ production was not heavily affected by recovery. The apparent lack of sensitivity to hydrostatic pressure, in conjunction with the close affiliation of hadal anammox bacteria to organisms from shallow waters, lends support to a recent hypothesis that due to continuous burial, obligate anaerobes in hadal sediments have little chance to diversify and thereby to establish specific adaptations such as piezophily (44). Instead, strains are selected from the seed stock that deposits from above and is buried through the oxic zone. We suggest that anammox bacteria, being a monophyletic clade with a well-defined obligate, anaerobic core metabolism (30), are excellent model organisms for further testing of this hypothesis.

This investigation was spurred by the report of high oxic respiration rates in hadal trenches, which reverse the general trend of decreasing benthic activity with increasing water depth $(5,8$, 45). For the Atacama and Kermadec Trenches, this trend was confirmed in a parallel study finding 1.3- to 3.5- and 2.8- to 4.6fold higher respiration rates, respectively, at our trench axis sites compared to the abyssal plain (11). Our results across two trenches consistently demonstrate an analogous stimulation of nitrogen cycling and, notably, a qualitative shift from the dominance of aerobic nitrification to anaerobic denitrification and anammox. We were not able to quantify $\mathrm{N}_{2}$ production at the abyssal sites, but our estimate of $\mathrm{N}_{2}$ production based on nitrate and ammonium fluxes to the nitrogenous zone in the Atacama and Kermadec Trench axes, $45 \pm 12$ and $26 \pm 8 \mu \mathrm{mol}$ $\mathrm{N} \cdot \mathrm{m}^{-2} \cdot \mathrm{d}^{-1}$, respectively, clearly exceeds the few tightly constrained estimates from abyssal settings: $5 \mu \mathrm{mol} \cdot \mathrm{m}^{-2} \cdot \mathrm{d}^{-1}$ at the Porcupine Abyssal Plain (4,800 m; ref. 15) and 5 to $13 \mu \mathrm{mol}$ $\cdot \mathrm{m}^{-2} \cdot \mathrm{d}^{-1}$ as integrated for the Canada Basin $(1,000$ to $4,000 \mathrm{~m}$; ref. 46), while our rates are comparable to rates from slope and rise at 2- to 3-km depth in the Atlantic and the Chukchi Sea $(28,47,48)$. It thus appears that anaerobic nitrogen transformations are stimulated at least as strongly as oxygen respiration in the trenches. This can be attributed to an increased deposition of reactive organic matter, which both provides a source of electron donors for denitrification and anammox and, through increased oxygen respiration, leads to a shoaling of the nitrogenous zone, bringing it closer to the source of reactive substrates. Although the areal extent of hadal trenches is too small for the enhanced activity to substantially impact the global marine nitrogen budget, our results emphasize the role of the trench sediments as hot spots in the deep sea and call for investigations of other anaerobic processes, including iron and sulfur cycling in these systems. Recent studies have shown that microbial communities in hadal sediments are taxonomically similar to those from shallower depths $(41,49)$. Our study complements these by demonstrating that the community carries out a similar suite of dissimilatory nitrogen transformations as its shallower counterparts. Moreover, our finding that anammox bacteria are not only key drivers of benthic nitrogen cycling but that those that thrive in the hadal axis sediments are closely related to strains from shallow waters and that their activity shows no marked effect of decompression from pressures up to 1,000 bar adds perspective to the general understanding of hadal trenches as an extreme environment. An extreme selective pressure is evident, e.g., for fish that are physiologically excluded as a group from living deeper than $\sim 8,400$ $\mathrm{m}(50)$, and both piezophily and piezosensitivity are well established for different types of bacteria (e.g., refs. 39, 40, and 51). Contrastingly, for anammox bacteria, our results suggest that biogeochemical conditions may play a stronger selective role than pressure in structuring the community.

\section{Materials and Methods}

Sediment was obtained during cruises on RV Tangaroa (TAN1711, 2017) and RV Sonne (SO261, 2018; ref. 52). We sampled six and four sites along the axis of the Atacama and Kermadec Trenches, respectively, one abyssal plain site in each trench region, and two sites at bathyal and abyssal depths, respectively, on the continental slope into the Atacama Trench (for locations and further descriptions, see refs. 11 and 20). All sites in the Atacama region (AT1-10), as well as Site KT6, were sampled by multicorer, while other Kermadec Trench samples were sampled by box corer. The multicorer cores and the box core from KT7 were brought on board with clear overlying water and visually undisturbed surfaces, while there was a risk for loss of the uppermost sediment in the box cores from KT3, 4, and 5. In cores with intact surfaces, there was a good agreement between the zone of nitrification, as inferred from profiles of porewater nitrate, and the oxygen penetration depth measured in situ by a benthic lander (11). Thus, we used nitrate profiles to estimate the sediment loss at the box-cored sites, and we infer losses of $\leq 1 \mathrm{~cm}$ at sites KT3 and KT4 but 5 to $7 \mathrm{~cm}$ at KT5. All sites were sampled into $9.4-\mathrm{cm}$ inner diameter core liners with duplicates taken for both porewater analysis and ${ }^{15} \mathrm{~N}$ tracer incubations. For all Atacama samples, duplicates were from two different multicorer casts, whereas for the Kermadec, samples were from the same cast.

Sediment cores were brought to a $3{ }^{\circ} \mathrm{C}$ cold room immediately after retrieval, and sectioning for porewater analysis typically began within $1 \mathrm{~h}$, followed by sectioning for incubations within $8 \mathrm{~h}$. For Atacama samples, all sectioning took place in an $\mathrm{N}_{2}$-filled glove bag, while Kermadec samples were sectioned under air. Porewater was extracted by centrifugation and split into aliquots for analysis of nitrate, nitrite, ammonium, and dissolved manganese, and for Atacama, for which the porewater was handled in the glove bag, also for dissolved iron and hydrogen sulfide, as previously described (53). Before sectioning, a sample of the overlying water was aliquoted similarly. Nitrate and nitrite were analyzed spectrophotometrically on fresh samples (54). Kermadec samples were also analyzed fresh for ammonium using the orthophenylanaline method (55), whereas for Atacama samples, this protocol was applied after frozen storage. Hydrogen sulfide was analyzed spectrophotometrically on fresh samples after preservation with $\mathrm{ZnCl}_{2}$ (56), while manganese and iron were analyzed on acidified samples stored cold using flame atomic absorption spectroscopy and spectrophotometry, respectively $(53,57)$. Detection limits were approximately $1,0.5,0.5,2,2$, and $1 \mu \mathrm{M}$ for nitrate, nitrite, ammonium, manganese, iron, and sulfide, respectively. Diffusive fluxes were estimated from concentration gradients using Fick's first law, with tortuosity correction and temperature-adjusted diffusion coefficients derived from ref. 58 using the gradient between two consecutive sections.

Rates and pathways of $\mathrm{N}_{2}$ production were determined in shipboard incubations using an adaptation of the ${ }^{15} \mathrm{~N}$ tracing technique $(24,59)$, including extra precautions against oxygen contamination, as we expected low rates of respiration and therefore saw a risk that oxygen respiration would not efficiently remove traces of oxygen present in upper horizons or introduced during handling. Parallel sections from two sediment cores were pooled, and $40 \mathrm{~cm}^{3}$ or $80 \mathrm{~cm}^{3}$ sediment was slurried, respectively, in 60 or $120 \mathrm{~mL}$ artificial seawater (35 psu) produced from Red Sea salt. Kermadec samples were sectioned in air, and aliquots quickly transferred to glass bottles that were sealed with butyl stoppers and flushed with $\mathrm{N}_{2}$ for $10 \mathrm{~min}$. Seawater for slurrying was degassed separately and transferred directly from its bottle to the slurry bottle via Viton tubing and needle through the stopper of the receiving bottle using $\mathrm{N}_{2}$ overpressure. Atacama samples were sectioned in an $\mathrm{N}_{2}$-filled glove bag and transferred to glass bottles already containing $\mathrm{N}_{2}$-degassed seawater. Subsequently, the headspace was flushed with $\mathrm{N}_{2}$ with intermittent shaking of the slurry.

For both trenches, the slurries were distributed into 6-mL Exetainers that were filled without a headspace in an $\mathrm{N}_{2}$-filled glove bag. The Exetainers were preamended with ${ }^{15} \mathrm{~N}$ tracer solutions, $25 \mu \mathrm{L}$ of either $50 \mathrm{mM} \mathrm{Na}{ }^{15} \mathrm{NO}_{3}$, $25 \mathrm{mM} \mathrm{Na}^{15} \mathrm{NO}_{2}$, or $100 \mathrm{mM}{ }^{15} \mathrm{NH}_{4} \mathrm{Cl}$, all $\geq 98 \%{ }^{15} \mathrm{~N}$. Some vials with ${ }^{15} \mathrm{NH}_{4}^{+}$ further received $25 \mu \mathrm{L} \mathrm{mM}$ unlabeled $50 \mathrm{mM} \mathrm{NaNO}_{3}$. Resulting final concentrations were approximately $100 \mu \mathrm{M} \mathrm{NO}_{3}^{-}, 50 \mu \mathrm{M} \mathrm{NO}_{2}^{-}$, and $200 \mu \mathrm{M} \mathrm{NH}_{4}$. Standard incubations included triplicates terminated by addition of $100 \mu \mathrm{L}$ $50 \% \mathrm{wt} / \mathrm{vol} \mathrm{ZnCl}_{2}$ at the beginning of the incubation and after $48 \mathrm{~h}$ (Atacama) or $72 \mathrm{~h}$ (Kermadec). For both trenches, additional time-course experiments were conducted to check for linearity of rates during these time intervals.

In addition to the shipboard incubations, we determined ${ }^{15} \mathrm{~N}-\mathrm{N}_{2}$ accumulation in intact sediment cores injected and incubated with ${ }^{15} \mathrm{~N}$-labeled nitrate or nitrite in situ using an autonomous benthic lander. Up to six $9.5-\mathrm{cm}$ i.d. acrylic core liners were pushed into the sediment by the lander while also 
vertically inserting three steel injection needles per core. The needles were positioned $4.5 \mathrm{~cm}$ apart in an equilateral triangle. Each needle had four rows of four holes near the tip through which water containing the tracer was ejected in a stepwise manner at a rate of $0.5 \mathrm{~mL} \cdot \mathrm{cm}^{-1}$ during insertion. The tracer solution was made up in artificial seawater, which was degassed and loaded without air contact into glass syringes each connected to one needle. As it was not possible to stop the incubation in situ, cores were injected at different times with the last injection representing the shortest incubation. We obtained data from two deployments at stations KT4 and KT10, respectively. At KT4, injections $\left(2 \times{ }^{15} \mathrm{NO}_{3}^{-}, 2 \times{ }^{-15} \mathrm{NO}_{2}{ }^{-}\right)$were made twice $48 \mathrm{~h}$ apart, while at KT10, injections were made five times at regular interval $\left(1 \times{ }^{15} \mathrm{NO}_{3}{ }^{-}, 1 \times\right.$ ${ }^{15} \mathrm{NO}_{2}{ }^{-}$) over $15 \mathrm{~h}$. After the last injections, the cores were retracted, the lander returned to the surface, and cores were brought to a cold room at $3^{\circ} \mathrm{C}$ after recovery. Here, the cores were subsampled by inserting $2.8-\mathrm{cm}$ i.d. acrylic cores around each needle. The sediment in these cores was sectioned into $2.5-\mathrm{cm}$ intervals, and two $2-\mathrm{mL}$ subsamples per section were quickly transferred to $6-\mathrm{mL}$ Exetainers, which were prefilled with water containing $0.8 \%$ $\mathrm{wt} / \mathrm{vol} \mathrm{ZnCl}_{2}$. The vials were sealed without a headspace and stored for ${ }^{15} \mathrm{~N}-\mathrm{N}_{2}$ analysis.

Accumulation of ${ }^{15} \mathrm{~N}$-labeled $\mathrm{N}_{2}$ was quantified using gas chromatography isotope ratio mass spectrometry after adding a helium headspace to the Exetainer as previously described (38). For the laboratory incubations, rates of denitrification and anammox were calculated according to ref. 58, with the labeled fractions of the substrate pools determined from the porewater concentration of unlabeled substrate and the added concentration of ${ }^{15} \mathrm{~N}$ label. For the lander incubations, rates of ${ }^{15} \mathrm{~N}-\mathrm{N}_{2}$ accumulation were calculated from linear regression of ${ }^{15} \mathrm{~N}-\mathrm{N}_{2}\left({ }^{29} \mathrm{~N}_{2}+2 \times{ }^{30} \mathrm{~N}_{2}\right)$ concentration versus time relative to the last injection.

Biomolecular analysis of the abundance and phylogeny of anammox bacteria in the sediments conducted in subsamples of the sediment used for incubations included qPCR of anammox $16 \mathrm{~S}$ rRNA genes and amplicon sequencing of the anammox-specific $h z s A$ gene. Furthermore, a deeply sequenced 165 rRNA gene amplicon dataset obtained with "universal" primers from separate sediment cores (44) was mined for anammox bacterial sequence variants. For qPCR and $h z s A$ sequencing, $\sim 1 \mathrm{~cm}^{3}$ of sediment was sampled while setting up incubations and frozen at $-80^{\circ} \mathrm{C}$. DNA was extracted from $\sim 0.25 \mu \mathrm{g}$ of this sediment using the DNeasy PowerSoil Kit (Qiagen) following the manufacturers recommendations. Quantification of $16 S$ rRNA genes via qPCR was conducted with the primer pair Brod541F (60) and AMX820R (61). Every 20- $\mathrm{L}$ qPCR reaction consisted of $10 \mu \mathrm{L}$ AMPLIQON RealQ Plus $2 x$ Master Mix Green, $1 \mu \mathrm{L}$ forward and reverse primer, $0.2 \mu \mathrm{L}$ bovine serum albumin (BSA), $2 \mu \mathrm{L}$ tem-

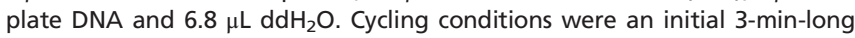
denaturation at $95^{\circ} \mathrm{C}$ followed by 50 loops of $95^{\circ} \mathrm{C}$ for $45 \mathrm{~s}, 60^{\circ} \mathrm{C}$ for $1 \mathrm{~min}$, or $72^{\circ} \mathrm{C}$ for $1 \mathrm{~min}$. Final elongation lasted $5 \mathrm{~min}$, followed by a melt curve from 50 to $95^{\circ} \mathrm{C}$ with an increment of $0.5^{\circ}$ every $5 \mathrm{~s}$.

Hydrazine synthase genes were amplified via a nested PCR (31). For the first step, we used the primer pair hzsA_382F and hzsA_2390R, while for the second step, hzsA_526F and hzsA_1857R were used with a 1:10 dilution step of the first PCR product. Each $50-\mu \mathrm{L}$ reaction contained $5 \mu \mathrm{L}$ deoxynuc leoside triphosphate, $5 \mu \mathrm{L} \mathrm{MgCl} 2,1 \mu \mathrm{L}$ forward and reverse primers, $5 \mu \mathrm{L}$ Taq Buf, $1 \mu \mathrm{L}$ BSA, $0.25 \mu \mathrm{L}$ Taq polymerase, $2 \mu \mathrm{L}$ template, and $29.75 \mu \mathrm{L} \mathrm{ddH}_{2} \mathrm{O}$. The PCR cycling conditions of the first step were initial 3-min denaturation at $95^{\circ} \mathrm{C}$ followed by 25 to 35 loops of $95^{\circ} \mathrm{C}$ for $1 \mathrm{~min}, 56^{\circ} \mathrm{C}$ for $1 \mathrm{~min}$, and $72^{\circ} \mathrm{C}$ for $2 \mathrm{~min}$, and a final elongation for $10 \mathrm{~min}$. The same conditions were used for the second step but with a $54^{\circ} \mathrm{C}$ annealing temperature. A small-scale test run of clone sequencing was done commercially at Macrogen Inc. before the PCR products were subjected to PacBio sequencing at the Vienna Biocenter Core Facilities Next Generation Sequencing Unit (https://www.viennabiocenter.org/ vbcf/). The clone sequences have been deposited in GenBank with the

1. R. N. Glud, Oxygen dynamics of marine sediments. Mar. Biol. Res. 4, 243-289 (2008).

2. D. E. Canfield, "Organic matter oxidation in marine sediments" in Interactions of $C$, $N, P$, and S Biogeochemical Cycles and Global Change, R. Wollast, F. T. MacKenzie, L. Chou, Eds. (Springer, 1993), pp. 333-363.

3. J. J. Middelburg, K. Soetaert, P. M. J. Herman, C. H. R. Heip, Denitrification in marine sediments: A model study. Global Biogeochem. Cycles 10, 661-673 (1996).

4. B. Thamdrup, T. Dalsgaard, "Nitrogen cycling in sediments" in Microbial Ecology of the Oceans, D. L. Kirchman, Ed. (Wiley \& Sons, ed. 2, 2008), pp. 527-568.

5. R. N. Glud et al., High rates of microbial carbon turnover in sediments in the deepest oceanic trench on Earth. Nat. Geosci. 6, 284-288 (2013).

6. R. Danovaro, N. Della Croce, A. Dell'Anno, A. Pusceddu, A depocenter of organic matter at $7800 \mathrm{~m}$ depth in the SE Pacific Ocean. Deep Sea Res. Part I Oceanogr. Res. Pap. 50, 1411-1420 (2003).

7. K. Oguri et al., Hadal disturbance in the Japan Trench induced by the 2011 TohokuOki earthquake. Sci. Rep. 3, 1915 (2013). accession numbers MW476708 through MW476731, while the PacBio data can be accessed at the National Centre for Biotechnology Information Sequence Read Archive (NCBI SRA) under PRJNA682892.

PacBio data of hzsA genes were demultiplexed and circular consensus reads generated using the SMRT Link Software package 5.1. Further processing of the circular consensus reads to ASVs was done subsequently with the DADA2 package (version 1.9.1) in the R Studio software environment (62). In parallel, $16 \mathrm{~S}$ rRNA gene data of anammox bacteria were extracted from the dataset of ref. 44 as amplicons classified either broadly in the candidate order Brocadiales or specifically in the candidate genera Anammoxoglobus, Brocadia, Jettenia, Kuenenia, or Scalindua. For phylogenetic analysis, reference sequences of anammox bacterial $16 \mathrm{~S}$ rRNA and $h z s A$ genes were mined from publicly available metagenomic datasets stored in the Integrated Microbial Genomes databases and the National Center for Biotechnology Information. Additional hydrazine synthase amino acid sequences were obtained by using Blast-p against the nonredundant database and clustered at $95 \%$ sequence similarity using usearch -cluster_fast (63). These reference datasets were manually filtered against short sequences and subsequently de novo aligned using mafft-linsi with standard parameters (64). Translated hzsA ASVs [Framebot (65)], clustered to $95 \%$ sequence similarity with usearch, and anammox 165 rRNA gene ASVs were added to the respective reference alignments using mafft-linsi with the -seed option. Phylogenetic trees were reconstructed using IQTree version 1.6.12 (66) based upon the entire alignment of hydrazine synthase sequences, while the 16S rRNA gene tree was based on the reference alignment with the short ASVs being mapped to the tree using the RAxML Evolutionary Placement Algorithm (EPA) (67). Model finder (68) suggested LG + G4 and TIM3 + F + R3 for hydrazine synthase and 16S rRNA genes, respectively, and branch support was calculated using 500 nonparametric bootstrap replicates. The resulting hydrazine synthase and 16S rRNA gene trees were visualized using $\mathrm{iTOL}$ and ggtree, respectively $(69,70)$, while relative abundances of anammox $16 \mathrm{~S}$ rRNA gene ASVs were plotted with Ampvis2 (71).

The biogeochemical dataset will be made available through the PANGAEA repository under the project title HADES-ERC (https://www.pangaea.de).

Data Availability. Biogeochemical data have been deposited in Zenodo (DOI: 10.5281/zenodo.5605478). All other study data are included in the article and/or SI Appendix. The clone sequences have been deposited in GenBank (https://www.ncbi.nlm.nih.gov/genbank/) with the accession nos. MW476708MW476731, while the PacBio data can be accessed at NCBI SRA under PRJNA682892.

ACKNOWLEDGMENTS. We thank the masters, crews, and scientific parties of RV Tangaroa (TAN1711; ship time partly funded by Coasts and Oceans Centre of New Zealand's National Institute of Water and Atmospheric Research, awarded to Ashley A. Rowden and R.N.G.) and RV Sonne (SO261; ship time provided by Federal Ministry of Education and Research, Germany, awarded to F.W., Mathias Zabel, and R.N.G.) for help with sampling. We thank Anni Glud, Lene A. Jakobsen, Heidi Grøn Jensen, Erik Laursen, and Louise R. Hansen for help with analyses, Johannes Lemburg for the construction of the Sediment-Lander, and Laura-Maria Bayer from the Vienna BioCenter Core Facilities for PacBio amplicon sequencing. Laura A. Bristow provided valuable comments on the manuscript. Financial support for the study was provided by European Research Council (ERC) Advanced Grant HADES No. 669947, by the Danish National Research Foundation through the Danish Center for Hadal Research, HADAL (No. DNRF145) awarded to R.N.G., and by ERC Advanced Grant NOVAMOX No. 695599 awarded to B. Thamdrup. RNA amplicon sequencing and analysis was carried out under the eDNAbyss (AP2016-228) Project funded by France Génomique (ANR-10INBS-09) and Genoscope under the supervision of Julie Poulain and Patrick Wincker.

8. F. Wenzhöfer et al., Benthic carbon mineralization in hadal trenches: Assessment by in situ $\mathrm{O}_{2}$ microprofile measurements. Deep Sea Res. Part I Oceanogr. Res. Pap. 116 276-286 (2016)

9. T. Nunoura et al., Molecular biological and isotopic biogeochemical prognoses of the nitrification-driven dynamic microbial nitrogen cycle in hadopelagic sediments. Environ. Microbiol. 15, 3087-3107 (2013).

10. T. Nunoura et al., Microbial diversity in sediments from the bottom of the Challenger Deep, the Mariana Trench. Microbes Environ. 33, 186-194 (2018).

11. R. N. Glud et al., Hadal trenches are dynamic hotspots for early diagenesis in the deep sea. Comm. Earth Environ. 2, 21 (2021)

12. D. E. Canfield, B. Thamdrup, Towards a consistent classification scheme for geochemical environments, or, why we wish the term 'suboxic' would go away. Geobiology 7, 385-392 (2009).

13. W. M. Berelson et al., Benthic fluxes and pore water studies from sediments of the central equatorial North Pacific - Nutrient diagenesis. Geochim. Cosmochim. Acta 54, 3001-3012 (1990) 
14. M. Haeckel, I. König, V. Reich, M. E. Weber, E. Suess, Pore water profiles and numerical modelling of biogeochemical processes in Peru Basin deep-sea sediments. Deep Sea Res. Part II Top. Stud. Oceanogr. 48, 3713-3736 (2001).

15. J. Brunnegård, S. Grandel, H. Stahl, A. Tengberg, P. O. J. Hall, Nitrogen cycling in deep-sea sediments of the Porcupine Abyssal Plain, NE Atlantic. Prog. Oceanogr. 63 159-181 (2004).

16. C. Hyacinthe, P. Anschutz, P. Carbonel, J.-M. Jouanneau, F. J. Jorissen, Early diage netic processes in the muddy sediments of the Bay of Biscay. Mar. Geol. 177, 111-128 (2001).

17. P. Engström, C. R. Penton, A. H. Devol, Anaerobic ammonium oxidation in deep-sea sediments off the Washington margin. Limnol. Oceanogr. 54, 1643-1652 (2009).

18. A. A. van de Graaf, P. de Bruijn, L. A. Robertson, M. S. M. Jetten, J. G. Kuenen, Metabolic pathway of anaerobic ammonium oxidation on the basis of ${ }^{15} \mathrm{~N}$ studies in a fluidized bed reactor. Microbiology (Reading) 143, 2415-2421 (1997).

19. S. Q. Liu, X. T. Peng, Organic matter diagenesis in hadal setting: Insights from the pore-water geochemistry of the Mariana Trench sediments. Deep Sea Res. Part I Oceanogr. Res. Pap. 147, 22-31 (2019).

20. C. Schauberger et al., Spatial variability of prokaryotic and viral abundances in the Kermadec and Atacama Trench regions. Limnol. Oceanogr. 66, 2095-2109 (2021)

21. M. Trimmer, P. Engström, "The environmental distribution, activity and ecology of anammox" in Nitrification, B. B. Ward, D. J. Arp, M. G. Klotz, Eds. (John Wiley \& Sons, 2011), pp. 201-235.

22. B. Thamdrup, New pathways and processes in the global nitrogen cycle. Annu. Rev. Ecol. Evol. Syst. 43, 407-428 (2012).

23. T. Dalsgaard, B. Thamdrup, D. E. Canfield, Anaerobic ammonium oxidation (anam mox) in the marine environment. Res. Microbiol. 156, 457-464 (2005).

24. T. Dalsgaard, B. Thamdrup, Factors controlling anaerobic ammonium oxidation with nitrite in marine sediments. Appl. Environ. Microbiol. 68, 3802-3808 (2002).

25. M. Trimmer, P. Engström, B. Thamdrup, Stark contrast in denitrification and anammox across the deep Norwegian trench in the Skagerrak. Appl. Environ. Microbiol. 79, 7381-7389 (2013).

26. D. E. Canfield et al., Pathways of organic carbon oxidation in three continental margin sediments. Mar. Geol. 113, 27-40 (1993).

27. P. Lam et al., Revising the nitrogen cycle in the Peruvian oxygen minimum zone. Proc. Natl. Acad. Sci. U.S.A. 106, 4752-4757 (2009).

28. M. Trimmer, J. C. Nicholls, Production of nitrogen gas via anammox and denitrification in intact sediment cores along a continental shelf to slope transect in the North Atlantic. Limnol. Oceanogr. 54, 577-589 (2009).

29. M. Oshiki, M. Ali, K. Shinyako-Hata, H. Satoh, S. Okabe, Hydroxylamine-dependent anaerobic ammonium oxidation (anammox) by "Candidatus Brocadia sinica". Environ. Microbiol. 18, 3133-3143 (2016).

30. B. Kartal et al., Molecular mechanism of anaerobic ammonium oxidation. Nature 479, 127-130 (2011).

31. H. R. Harhangi et al., Hydrazine synthase, a unique phylomarker with which to study the presence and biodiversity of anammox bacteria. Appl. Environ. Microbiol. $\mathbf{7 8}$ 752-758 (2012)

32. D. Woebken et al., A microdiversity study of anammox bacteria reveals a novel Candidatus Scalindua phylotype in marine oxygen minimum zones. Environ. Microbiol. 10, 3106-3119 (2008)

33. S. Ganesh et al., Single cell genomic and transcriptomic evidence for the use of alternative nitrogen substrates by anammox bacteria. ISME J. 12, 2706-2722 (2018).

34. O. Ulloa, D. E. Canfield, E. F. DeLong, R. M. Letelier, F. J. Stewart, Microbial oceanog raphy of anoxic oxygen minimum zones. Proc. Natl. Acad. Sci. U.S.A. 109, 15996-16003 (2012).

35. H. Dang et al., Molecular detection of Candidatus Scalindua pacifica and environmental responses of sediment anammox bacterial community in the Bohai Sea, China. PLoS One 8, e61330 (2013).

36. B. Thamdrup, H. Fossing, B. B. Jørgensen, Manganese, iron, and sulfur cycling in a coastal marine sediment, Aarhus Bay, Denmark. Geochim. Cosmochim. Acta 58 5115-5129 (1994)

37. A. Galán et al., Anammox bacteria and the anaerobic oxidation of ammonium in the oxygen minimum zone off northern Chile. Deep Sea Res. Part II Top. Stud. Oceanogr. 56, 1125-1135 (2009).

38. T. Dalsgaard, B. Thamdrup, L. Farias, N. P. Revsbech, Anammox and denitrification in the oxygen minimum zone of the eastern South Pacific. Limnol. Oceanogr. 57, 1331-1346 (2012)

39. A. A. Yayanos, Microbiology to 10,500 meters in the deep sea. Annu. Rev. Microbiol. 49, 777-805 (1995)

40. C. Tamburini, M. Boutrif, M. Garel, R. R. Colwell, J. W. Deming, Prokaryotic responses to hydrostatic pressure in the ocean-A review. Environ. Microbiol. 15, 1262-1274 (2013).

41. L. M. Peoples et al., Microbial community diversity within sediments from two geographically separated hadal trenches. Front. Microbiol. 10, 347 (2019).

42. W. R. van der Star et al., The membrane bioreactor: A novel tool to grow anammox bacteria as free cells. Biotechnol. Bioeng. 101, 286-294 (2008).
43. S. Sokoll et al., Extensive nitrogen loss from permeable sediments off north-west Africa. J. Geophys. Res. Biogeosci. 121, 1144-1157 (2016).

44. C. Schauberger et al., Microbial community structure in hadal sediments: High similarity along trench axes and strong changes along redox gradients. ISME J., 10.1038/ s41396-021-01021-w (2021)

45. M. Luo et al., Benthic carbon mineralization in hadal trenches: Insights from in situ determination of benthic oxygen consumption. Geophys. Res. Lett. 45, 2752-27605 (2018).

46. J. L. Reeve, R. C. Hamme, W. J. Williams, Tracing denitrification in the Canada Basin: $\mathrm{N}_{2}$ loss to the atmosphere on the Chukchi Shelf and benthic inputs in deep waters. Deep Sea Res. Part I Oceanogr. Res. Pap. 143, 127-138 (2019).

47. W. R. Martin, F. L. Sayles, Organic matter cycling in sediments of the continental margin in the northwest Atlantic Ocean. Deep Sea Res. Part I Oceanogr. Res. Pap. 51, 457-489 (2004).

48. B. X. Chang, A. H. Devol, Seasonal and spatial patterns of sedimentary denitrification rates in the Chukchi Sea. Deep Sea Res. Part II Top. Stud. Oceanogr. 56, 1339-1350 (2009).

49. S. Hiraoka et al., Microbial community and geochemical analyses of trans-trench sediments for understanding the roles of hadal environments. ISME J. 14, 740-756 (2020).

50. P. H. Yancey, M. E. Gerringer, J. C. Drazen, A. A. Rowden, A. Jamieson, Marine fish may be biochemically constrained from inhabiting the deepest ocean depths. Proc. Natl. Acad. Sci. U.S.A. 111, 4461-4465 (2014).

51. L. M. Peoples et al., Distinctive gene and protein characteristics of extremely piezophilic Colwellia. BMC Genomics 21, 692 (2020)

52. F. Wenzhöfer, The expedition SO261 of the research vessel SONNE to the Atacama Trench in the Pacific Ocean in 2018. 10.2312/BzPM_0729_2019. Accessed 3 November 2021.

53. B. Thamdrup, D. E. Canfield, Pathways of carbon oxidation in continental margin sediments off central Chile. Limnol. Oceanogr. 41, 1629-1650 (1996).

54. E. García-Robledo, A. Corzo, S. Papaspyrou, A fast and direct spectrophotometric method for the sequential determination of nitrate and nitrite at low concentrations in small volumes. Mar. Chem. 162, 30-36 (2014).

55. R. M. Holmes, A. Aminot, R. Kerouel, B. A. Hooker, B. J. Peterson, A simple and precise method for measuring ammonium in marine and freshwater ecosystems. Can. J. Fish. Aquat. Sci. 56, 1801-1808 (1999).

56. J. D. Cline, Spectrophotometric determination of hydrogen sulfide in natural waters. Limnol. Oceanogr. 14, 454-458 (1969).

57. L. L. Stookey, Ferrozine - A new spectrophotometric reagent for iron. Anal. Chem. 42 779-781 (1970).

58. B. P. Boudreau, Diagenetic Models and Their Implementation (Springer, 1997)

59. B. Thamdrup, T. Dalsgaard, Production of $\mathrm{N}(2)$ through anaerobic ammonium oxidation coupled to nitrate reduction in marine sediments. Appl. Environ. Microbiol. 68 1312-1318 (2002).

60. C. R. Penton, A. H. Devol, J. M. Tiedje, Molecular evidence for the broad distribution of anaerobic ammonium-oxidizing bacteria in freshwater and marine sediments. Appl. Environ. Microbiol. 72, 6829-6832 (2006).

61. M. Schmid et al., Molecular evidence for genus level diversity of bacteria capable of catalyzing anaerobic ammonium oxidation. Syst. Appl. Microbiol. 23, 93-106 (2000).

62. B. J. Callahan et al., DADA2: High-resolution sample inference from Illumina amplicon data. Nat. Methods 13, 581-583 (2016).

63. R. C. Edgar, Search and clustering orders of magnitude faster than BLAST. Bioinformatics 26, 2460-2461 (2010).

64. K. Katoh, K. Kuma, H. Toh, T. Miyata, MAFFT version 5: Improvement in accuracy of multiple sequence alignment. Nucleic Acids Res. 33, 511-518 (2005).

65. Q. Wang et al., Ecological patterns of nifH genes in four terrestrial climatic zones explored with targeted metagenomics using FrameBot, a new informatics tool. mBio 4, e00592-13 (2013)

66. L.-T. Nguyen, H. A. Schmidt, A. von Haeseler, B. Q. Minh, IQ-TREE: A fast and effective stochastic algorithm for estimating maximum-likelihood phylogenies. Mol. Biol. Evol. 32, 268-274 (2015)

67. S. A. Berger, D. Krompass, A. Stamatakis, Performance, accuracy, and Web server for evolutionary placement of short sequence reads under maximum likelihood. Syst. Biol. 60, 291-302 (2011)

68. S. Kalyaanamoorthy, B. Q. Minh, T. K. F. Wong, A. von Haeseler, L. S. Jermiin, ModelFinder: Fast model selection for accurate phylogenetic estimates. Nat. Methods 14, 587-589 (2017).

69. I. Letunic, P. Bork, Interactive Tree Of Life (iTOL): An online tool for phylogenetic tree display and annotation. Bioinformatics 23, 127-128 (2007).

70. G. Yu et al., Ggtree: An R package for visualization and annotation of phylogenetic trees with their covariates and other associated data. Methods Ecol. Evol. 8, 28-36 (2017).

71. K. S. Andersen, R. H. Kirkegaard, S. M. Karst, M. Albertsen, Ampvis2: An R package to analyse and visualise 16S rRNA amplicon data. bioRxiv [Preprint] (2018). https://doi. org/10.1101/299537 (Accessed 1 September 2021). 